УДК 378.147:004.457.:37.091.4Froebel's (045)(477.82)

DOI: $\underline{10.35619 / \mathrm{iiu} . v 2 \mathrm{i} 11.214}$

Денисенко Наталія

кандидат педагогічних наук, доцент кафедри здоров'я людини та фізичної реабілітації

Академії рекреаційних технологій і права, викладач фахових методик фізичного виховання,

м. Луцьк, Україна

ORCID: 0000-0001-5730-0221

e-mail: Zaochnevid@gmail.com

Бортнюк Тетяна кандидат економічних наук, викладач економіки Луцького педагогічного коледжу, м. Луцьк, Україна

ORCID: 0000-0001-9673-1366 e-mail:Tanya.bortnyuk@gmail.com

Найт Надія

магістр філології, аспірант

Східноєвропейського національного університету імені Лесі Українки, викладач словесних дисциплін Луцького педагогічного коледжу, м. Луцьк, Україна

ORCID: 0000-0002-3520-1756 e-mail: nadiaknight23@gmail.com

Стасюк Дар'я спеціаліст дошкільної освіти, аспірант Східноєвропейського національного університету імені Лесі Українки, викладач фахових методик дошкільної освіти Луцького педагогічного коледжу, м. Луцьк, Україна ORCID: 0000-0002-4073-7483 e-mail: dasha-sinaya@ukr.net

\title{
ІННОВАЦІЙНА ПЕДАГОГІКА Ф. ФРЕБЕЛЯ ЧЕРЕЗ ОНЛАЙН-СЕРВІС «РRЕZІ»
}

\begin{abstract}
Анотація. У статті зазначено, що застосування інформаційних технологій, мультимедійних засобів та різних онлайн-сервісів значно розширюють можливості освітнього процесу, забезпечують нові шляхи подачі інформації, створюють можливості для випробування власних ідей та проєктів, сприяють кращому сприйняттю та засвоєнню знань, зростанню інтересу до пізнання, індивідуалізації навчання, посиленню мотивації та динамічній подачі матеріалу. Підкреслено, що програмні продукти презентаційного характеру частково виконують функції підручників і навчальних посібників, що значно
\end{abstract}


спрощують процес підготовки вчителя нового покоління в умовах педагогічного коледжу. Проаналізовано результати опитування студентів педагогічних коледжів 3 питань їх підготовленості до впровадження педагогічної спадщини Ф. Фребеля в подальшій професійній діяльності.

Вивчено думку студентів щодо ефективності застосування фребелівського дидактичного матеріалу, спрямованого на розвиток фізичних здібностей дітей, їх здатності до конструктивної діяльності, яка набуває сьогодні особливої значущості тому, що вона $є$ базовою якістю людини, іiі ядром, центральною характеристикою творчої особистості. Подано рекомендації щодо застосування авторських словесних ігор українською та англійською мовами, які зібрано колективом викладачів Луцького педагогічного коледжу у міні-підручнику «Ідеї Ф. Фребеля в дії: теорія і практика сьогодення». Акцентовано увагу на значенні хмарного онлайн-сервісу «Prezi» щодо створення навчального матеріалу для оволодіння методикою використання ігрового набору «Дари Фребеля» в роботі з дітьми дошкільного та молодшого шкільного віку. Розроблено практичні рекомендації для застосування готових презентацій, розроблених в хмарному онлайн-сервісі «Prezi», а також систематизовано їх електронні адреси. Підкреслено, що інформаційні технології допоможуть у майбутньому створювати авторські навчальні матеріали для вдосконалення процесу викладання методики використання «дарунків» Фребеля в освітньому середовищі як закладу дошкільної освіти, так і в умовах нової української школи.

Ключові слова. «Дарунки» Ф. Фребеля, мультимедіа, мультимедійні сервіси, хмарний сервіс, онлайн-сервіс, «Prezi», словесні ігри, майбутні фахівці, сучасні діти.

Постановка проблеми. Стрімкі темпи сучасного суспільства призвели до значних змін у повсякденному житті та професійній діяльності педагогів. Інформатизація освіти $\epsilon$ першорядною умовою підготовки компетентних педагогів, здатних працювати в середовищі, що постійно змінюється в умовах глобалізації та дедалі більше автоматизованих умовах праці. 3 метою забезпечення ефективності навчання суттєвого значення набуває реалізація онлайн-сервісу «Prezi», який підсилює прикладну освітню складову в системі підготовки майбутнього педагога, особливо у розв'язанні питань, що пов'язані з використанням інноваційних педагогічних технологій, зокрема педагогічної спадщини відомого німецького педагога Фрідріха Фребеля.

Безумовно, що підготовка висококваліфікованих педагогічних працівників, які відповідають сучасним ринковим вимогам в умовах інформаційного суспільства та вимогам реформи «Нова українська школа», є однією з важливих структурних компонентів системи вищої освіти України. Інформатизація є обов'язковим процесом у всіх сферах людської діяльності. Саме тому у Законах України «Про освіту», «Про вищу освіту», а також у Національній стратегії розвитку освіти в Україні на період до 2021 року важливим завданням вищої педагогічної освіти визначено підвищення інформаційно-комунікаційної компетентності педагогічних кадрів, здатних забезпечувати інноваційний поступ сучасної системи освіти. I це не випадково, адже концентрація дитячої уваги - одна 3 найбільших проблем сучасних підлітків. Діти люблять, коли на уроках замість текстів їм пропонують картинки та інфографіки, - тільки так можна впоратися з великою кількістю інформації, яку вони отримують щодня. Діти «фотографують» реальність очима, тому ми все більше чуємо, що сучасні діти не читають, а віддають перевагу побаченому над прочитаним. Причому, вони більше люблять подання інформації блогерами, а не викладачами зі старих підручників. Адже будь-яка інформація має бути розглянута під різними кутами, давати змогу глибше усвідомити проблему та сформувати власну думку. Підлітки знають, за якими 
законами існує інформація і як краще «зачепити» аудиторію. Вони багатозадачні і можуть щось вирішити за секунду, не маючи бажання витрачати час на щось нецікаве. Тому вже зараз треба формувати у дітей інформаційні компетентності, поєднувати в освітньому процесі технічні предмети з такими, що розвивають креативність, як-от живопис, фізичний розвиток та програмування.

Такі особливості дітей нового покоління дають можливості педагогу моделювати такий освітній процес, що ототожнює національні традиції на принципах свободи розвитку творчих здібностей учнів, креативності їх мислення та створення навчально-предметного середовища, які в сукупності забезпечують психологічний комфорт, чудовий фізичний розвиток, уміння працювати над проєктами в команді, інформаційну грамотність і навички ефективного використання інформаційного середовища.

Серед різних методик для теорії і практики дошкільної і початкової освіти значущими $\epsilon$ ідеї видатного педагога-реформатора Фрідріха Фребеля, які збагачують і осучаснюють освітнє середовище та педагогічну думку в ньому ідеями соціального захисту дитинства, мають універсальну педагогічну поліфонію та методичну цінність. Вивчення творчого доробку вченого доводить співзвучність його ідей із сьогоднішніми концептуальними положеннями національної системи освіти, які можуть бути підсилені використанням інформаційно-комунікаційних технологій, що дозволяе створювати засоби демонстраційного супроводу інформації й використовувати їх на лекційних і практичних заняттях у вищій школі.

Зокрема, застосовувати сьогодні на практиці фребель-педагогіку можна за допомогою сучасних комп'ютерних програм, які представлені у великій кількості. Насамперед, це Google Slides, Prezi, Keynote, PowToon, Canva, Emaze, ZohoShow та інші. Однак для реалізації дидактичного принципу наочності викладачі закладів вищої освіти педагогічного спрямування зосереджують свою увагу на додатку PowerPoint, який $є$ прикладною програмою пакета Microsoft Office. Попри таку популярність це не означає, що альтернативи цій програмі немає. Пошуки можливостей органічного поєднання і взаємоузгодження програмних продуктів для створення презентацій, спонукали до виявлення й ознайомлення 3 новим сервісом Prezi, який дозволяє оперувати даними, ефективно демонструвати навчальну інформацію про застосування на практиці дарунків Фребеля.

Аналіз останніх досліджень 3 проблеми. У наукових дослідженнях М. Б. Лебедевої та О. Н. Шилової визначено, що інформаційно-комунікаційна компетентність може розглядатися як якість особистості вчителя, що включає сукупність знань, умінь і навичок виконання різних видів інформаційної і комунікаційної діяльності; безпосередньо пов'язана зі сферою його професійної діяльності; як складова професійної компетентності фахівця; як етап у становленні його інформаційної культури, інформаційної грамотності та інформаційної діяльності (Лебедева та Шилова, 2004). Таке нове розуміння формування інформаційно-мобільного вчителя створює умови для формування його нових світоглядних орієнтирів, що узгоджуються з ідеалами формування «унікальної дитини» за Ф. Фребелем, які постали перед сучасною цивілізацією.

Теорію Ф. Фребеля оцінювали та критикували, застосовували на практиці та забороняли як в європейських країнах, так і в Росії й Україні. Його дидактичним матеріалом («Дарами» Ф. Фребеля) цікавились такі відомі педагоги, як К. Ушинський, М. Пирогов, П. Каптерев, П. Лесгафт, С. Русова, С. Шацький. Аналізуючи роботи Фрідріха Фребеля, вищезазначені педагоги, висвітлюючи той чи інший аспект його діяльності, та, намагаючись осягнути філософські основи його педагогічної теорії, прагнули до систематизації теоретичної 
спадщини видатного педагога, виділення іiї сильних та слабких сторін, узагальнення досвіду роботи.

Серед сучасних досліджень фребель-педагогіки слід відзначити наукові студії О. Анісімової («Методологічні основи педагогічної системи Ф. Фребеля», 2013) (Анісімова, 2013); Л. Петухової («Фрьобель-педагогіка - шлях до інтеграції освітніх систем України та Німеччини», 2011) (Петухова, 2011); О. Полєвікової («Інтеграція сучасних освітніх систем Європи та світу в контексті впровадження педагогічних ідей Ф. Фрьобеля», 2012) (Полєвікова, 2012); І. Брушневської («Використання ідей Ф. Фребеля в корекційній роботі 3 дітьми дошкільного віку», 2017) (Брушневська, 2017); Д. Стасюк («Дарунки Ф. Фребеля як альтернативна логопедична технологія у подоланні мовленнєвих розладів у дітей дошкільного віку») (Стасюк, 2019) та ін.

Водночас усі вони сходяться на тому, що рушійною силою розвитку Ф. Фребель уважав саморозвиток, закладений у природі й у людині, що нібито спонукає особистість до прояву себе в зовнішніх діях - зображувальних, пізнавальних, мовних, фізичних та ін. За його твердженням, «розвиток - це безперервний процес прояву руху внутрішньої сили людини, в ході якого відображаються основні етапи духовного розвитку попередніх поколінь. Однак, розвиваючись, дитина повторює пройдене попередніми поколіннями не сліпо, а в творчій самодіяльності - у мовленні, малюнках, будуванні, іграх. Вона пізнає світ емпірично завдяки властивим їй рухам і органам чуття. Людина, стверджував педагог, є творча істота, а тому потрібно виховувати людину праці, справи, бо саме в діяльності й творчості гармонійно розвиваються і формуються сили й здібності» (Фребель, 1974). I тому важливий блок педагогічної системи відомого педагога складає дидактичний матеріал, з яким повинна працювати дитина («дарунки Фребеля»).

I якщо ми зацікавлені в тому, аби Україна боролася не просто за виживання, а за вихід на фарватер нового педагогічного розвитку, то саме 3 цією стратегією потрібно співвідносити ідеї «фребель-педагогіки» й «цінності освіти», зорієнтовані на формування інформаційно-комунікаційної компетентності педагога нового покоління. Водночас проєктування комп'ютерних презентацій засобами сервісу Prezi iдей Ф. Фребеля, адаптованих до сучасних умов, дозволить створити сприятливе освітнє середовище для представників нового покоління.

Мета статті - визначити умови запровадження фребель-педагогіки в систему підготовки майбутнього педагога через онлайн-сервіс «Prezi», що забезпечує нові шляхи подачі інформації та сприяє кращому сприйняттю і засвоєнню знань, зростанню інтересу до пізнання, індивідуалізації навчання, посиленню мотивації та динамічній подачі матеріалу; привернення уваги педагогічної громадськості до реалізації в освітньому просторі дарів Ф. Фребеля на прикладі хмарного онлайн-сервісу Prezi як альтернативного й ефективного засобу для створення електронних презентацій. Для досягнення мети та розв'язання поставлених завдань використано комплекс методів дослідження:

- теоретичні: аналіз, синтез, порівняння, систематизація, класифікація, моделювання 3 метою узагальнення теоретичних матеріалів, обгрунтування змісту, форм i методів підготовки майбутніх учителів до впровадження педагогічних ідей Ф. Фребеля;

- узагальнення та систематизація досвіду застосування на прикладі хмарного онлайнсервісу Prezi.

Виклад основного матеріалу дослідження. Для успішного завершення навчання у закладах освіти педагогічного спрямування бажано, щоб студенти здійснили деякий «якісний» стрибок, що дозволить їм інтегрувати інформацію про ІКТ, яку вони здобули 3 педагогікою застосування ідей Ф. Фребеля в єдину систему. Безумовно, що межі між цими 
дисциплінами проведені досить умовно, і здебільшого неможливо вирішити важливих проблем (як практичних, так і теоретичних) в межах однієї вузької проблеми.

Як зауважує Д. Соменко (Соменко, 2015), один з можливих варіантів вирішення цієї задачі є завдання спроєктувати різні знання та уміння, набуті в процесі навчання, на певну проблемну галузь, що дає можливість для їх зіставлення та «діалогу» між ними. Інформаційно-комунікаційні технології досить вдало виступають основою для цього, оскільки викликають інтерес представників найрізноманітніших галузей педагогічних наук і напрямів. Тому сучасний стан формування інформаційно-комунікаційної компетентності педагогічних кадрів, здатних впроваджувати ідеї педагогіки Ф. Фребеля у подальшій професійній діяльності, вивчався у процесі проведення анкетування, педагогічних спостережень, бесід серед студентів педагогічних коледжів, у якому взяли участь 173 особи 3-4 курсів. Респондентами виступили 45 студентів Луцького педагогічного коледжу, 53 здобувачі вищої освіти КЗ ЛОР «Самбірського педагогічного коледжу імені Івана Филипчака», 50 студентів Вінницького гуманітарно-педагогічного коледжу і 25 студентів Бахмутського педагогічного коледжу.

Проаналізуємо деякі з них.

Результати відповідей на запитання анкети «Чи вважаєте Ви себе підготовленими до впровадження педагогічної спадщини Ф. Фребеля в подальшій професійній діяльності?» свідчать про те, що із 173 студентів повністю підготовленими вважають себе 43,07\%, не підготовленими - 25,32\%, важко було відповісти - 31,6\% студентів (рис. 1 ).

У процесі дослідження було також з'ясовано, що 73,4\% опитаних студентів зацікавленні у підвищенні рівня оволодіння фребелівськими методиками в роботі з дітьми та застосувати ïх можливості у професійній діяльності через створення відповідного «інформаційноосвітнього середовища» (IOC). $65,8 \%$ респондентів стверджують, що застосування мультимедійних презентацій підвищує інтенсивність вивчення навчального матеріалу; 69,6\% - вважають, що це сприяє усуненню територіальних бар'єрів у процесі використання дарів Ф. Фребеля на практиці; 71,8\% опитаних вважають, що мультимедійні засоби навчання допомагають краще зрозуміти і запам'ятати словесні ігри, які є обов'язковими при застосуванні педагогіки Ф. Фребеля; 86,7\% опитаних студентів зі всіх закладів освіти вважають, що засоби мультимедіа спрощують стратегію застосування дарів Ф. Фребеля на практиці у різновікових групах дітей дошкільного і молодшого шкільного віку; 68,4\% переконані, що інформаційні технології допоможуть у майбутньому створювати авторські навчальні матеріали для вдосконалення процесу викладання методики використання дарів Фребеля в освітньому середовищі. 


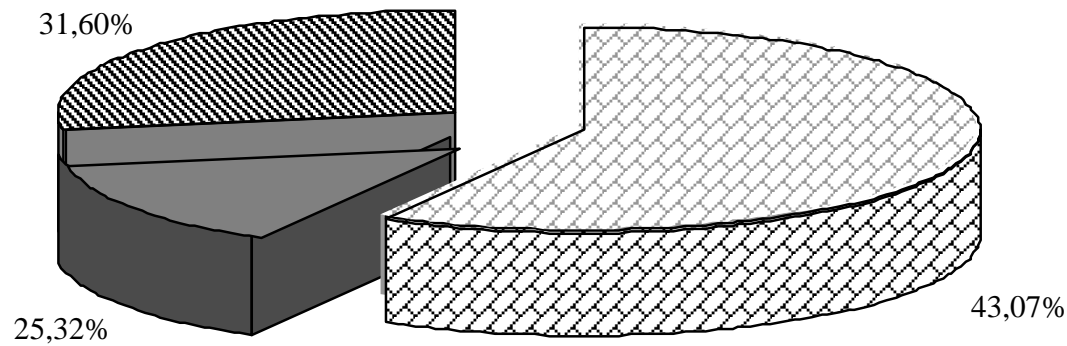
乙 Володіють знаннями
$\square$ Не володіють знаннями
椾 Важко було відповісти

Puc. 1. Підготовленість студентів до впровадження педагогічної спадщини Ф. Фребеля в подальшій професійній діяльності

У процесі дослідження вивчалась думка студентів щодо використання сучасних комп'ютерних програм на заняттях з оволодіння методикою застосування дарів Фребеля. На запитання анкети «Які програми для створення презентацій Ви вважаєте найбільш ефективними для розкриття змісту і переваг використання фребелівських методик у роботі 3 дітьми?» відповіді, що подані у таблиці 1, розподілилися у такий спосіб: із 173 студентів надають перевагу PowerPoint 44,62\%; Prezi - 26,96\%; Google Slides-7,58 \%; Sparkol Videoscribe- 9,17\%; Creately-7,62\%; Infogr.am- 4,05\% (табл.1).

Таблиия 1

Результати відповідей студентів на предмет надання переваги програмам зі створення презентацій (\%)

\begin{tabular}{|c|c|c|c|c|c|c|c|c|c|}
\hline \multirow[b]{3}{*}{ Відповіді } & \multirow{3}{*}{ 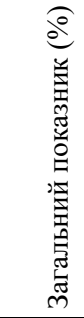 } & \multicolumn{8}{|c|}{ Педагогічні коледжі } \\
\hline & & \multicolumn{2}{|c|}{$\begin{array}{c}\text { ЛПК } \\
\text { Луцький } \\
\text { педагогічний } \\
\text { коледж }\end{array}$} & \multicolumn{2}{|c|}{$\begin{array}{c}\text { КЗ ЛОР } \\
\text { «Самбірський } \\
\text { педагогічний } \\
\text { коледж імені } \\
\quad \text { Івана } \\
\text { Филипчака» }\end{array}$} & \multicolumn{2}{|c|}{$\begin{array}{c}\text { Вінницький } \\
\text { гуманітарно- } \\
\text { педагогічний } \\
\text { коледж }\end{array}$} & \multicolumn{2}{|c|}{$\begin{array}{c}\text { Бахмутський } \\
\text { педагогічний } \\
\text { коледж }\end{array}$} \\
\hline & & $\begin{array}{c}45 \\
\text { чол. }\end{array}$ & $\%$ & $\begin{array}{c}53 \\
\text { чол. }\end{array}$ & $\%$ & $\begin{array}{c}50 \\
\text { чол. }\end{array}$ & $\%$ & $\begin{array}{c}25 \\
\text { чол. }\end{array}$ & $\%$ \\
\hline PowerPoint & 44,62 & 16 & 35,6 & 27 & 50,9 & 24 & 48,0 & 11 & 44,0 \\
\hline Prezi & 26,96 & 15 & 33,3 & 13 & 24,5 & 15 & 30,0 & 5 & 20,0 \\
\hline Google Slides & 7,58 & 4 & 8,9 & 5 & 9,4 & 2 & 4,0 & 2 & 8,0 \\
\hline SparkolVideoscribe & 9,17 & 5 & 11,1 & 4 & 7,6 & 3 & 6,0 & 3 & 12,0 \\
\hline
\end{tabular}




\begin{tabular}{|l|c|c|c|c|c|c|c|c|c|}
\hline Creately & 7,62 & 3 & 6,7 & 2 & 3,8 & 4 & 8,0 & 3 & 12,0 \\
\hline Infogr.am & 4,05 & 2 & 4,4 & 2 & 3,8 & 2 & 4,0 & 1 & 4,0 \\
\hline
\end{tabular}

Цей показник переконливо ілюструє рис.2.

Зважаючи на зацікавленість студентів педагогічними ідеями Ф. Фребеля, нами було розроблено методичний посібник «Використання ігрового набору «Дари Фребеля», який передбачав оволодіння студентами методикою застосування на практиці словесними іграми з використанням «дарів № 1,2,3». 3 метою кращого розуміння і запам'ятовування словесних ігор, був застосований хмарний онлайн-сервіс «Prezi», оскільки він $є$ дуже популярним серед студентів педагогічних спеціальностей (друге місце у рейтингу) і пропонує велику кількість можливостей для візуалізації презентацій.

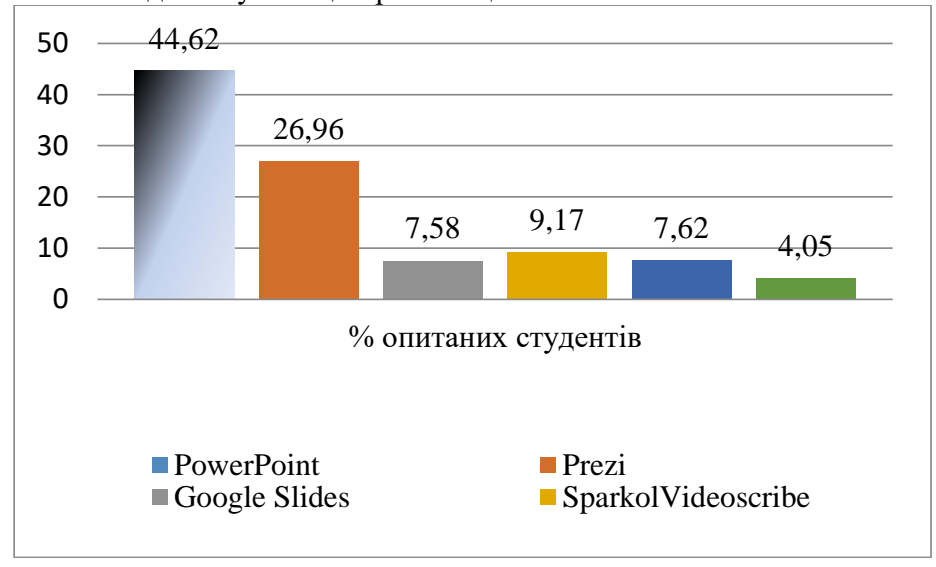

Puc. 2. Аналіз популярності серед студентів педагогічних спеціальностей представлених програм PowerPoint, Prezi, Google Slides, Sparkol Videoscribe, Creately, Infogr.am для оволодіння фребелівською методикою

Термін «Рrezi» 3 угорської транслюється як скорочена форма слова «презентація». Проєкт має девіз «Ideas matter», що в перекладі означає «зосередитися на ідеях», «впорядкувати важливі думки». Prezi.com - це веб-сервіс, за допомогою якого можна створити інтерактивні мультимедійні презентації 3 нелінійною структурою. Сервіс пропонує велику кількість можливостей для візуалізації презентацій за допомогою використання, графіки, текстових блоків, стікерів, геометричних фігур, картинок, відеороликів, звукових доріжок (Бондаренко, 2018), які стануть в нагоді сучасному вчителю.

Інтерфейс програми англійською мовою, але візуалізація та піктограми керування зроблені так, щоб можна було навчитися використовувати Prezi на інтуїтивному рівні.

Для початку створення нової презентації потрібно натиснути кнопку New Prezi. Після цього відкриється нова вкладка браузера, в якій першочергово запропонують обрати один 3 багатьох шаблонів. Зазначимо, при створенні власних презентацій, які віддзеркалювали індії гребель-педагогіки, ми обирали варіант Start blank prezi (усі малюнки - розробка автора) (рис.3.). 


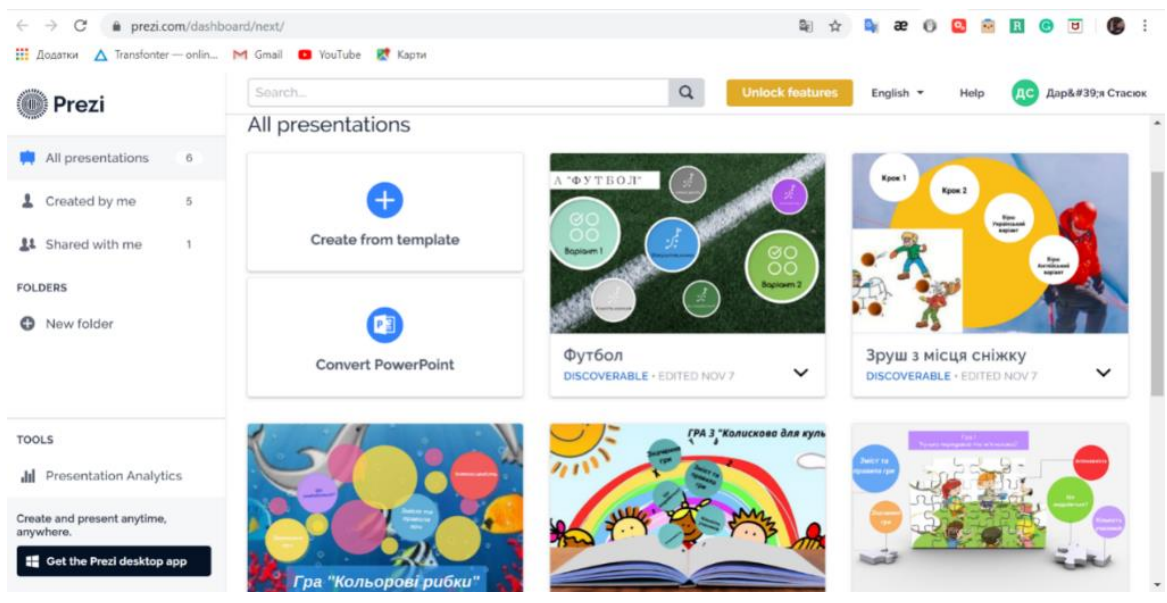

Puc. 3.Домашня сторінка існуючого користувача

Обравши потрібний шаблон та адаптувавши його до певного «фребелівського дару», ми отримували основу, яку налаштовували за таким алгоритмом: значення гри; інтенсивність гри; кількість учасників; що знадобиться (матеріально-технічне забезпечення та зображення конкретного номеру дару Ф. Фребеля); покроковий зміст та правила словесної гри, які пояснює інструктор-тьютор українською та англійською мовами; музичний супровід та відео-матеріали (у разі потреби).

На будь-якому етапі роботи проглядали результати власної діяльності завдяки кнопці Present. Сервіс Prezi автоматично зберігає роботу з внесеними корективами.

Слід зауважити, що опції збереження роботи в Prezi ширші, ніж у стандартних програмах для створення презентацій, що $є$ зручним для викладача в процесі подачі навчальної інформації. По-перше, з'являється посилання на сторінку з презентацією. Подруге, $є$ можливість проводити онлайн-презентації для студентів дистанційної фори навчання. По-третє, з'являється перспектива для генерування спеціальної сторінки, що працює впродовж обмеженого часу, та на яку запрошені студенти окремих спеціальностей (фізичне виховання, дошкільна і початкова освіті, зокрема маленькими групами). Майбутні педагоги мають змогу слідкувати за презентацією з конкретним дидактичним матеріалом. По-четверте, усі презентації зберігаються у форматі PDF. По-п’яте, можна завантажувати на власний комп'ютер автономний варіант презентації для використання у разі відсутності з'єднання з Інтернетом.

Висновки і перспективи подальших розвідок. Застосування комп'ютерів в освіті забезпечило появу нового покоління інформаційних освітніх технологій, що дали змогу підвищити якість навчання, створити нові засоби впливу, ефективніше взаємодіяти педагогам зі студентами. Проведене дослідження організації середовища Prezi як ефективного засобу для створення цікавих навчальних презентацій уможливило отримання таких наукових результатів: 73,4\% респондентів зацікавленні у підвищенні рівня оволодіння фребелівськими методиками за умовою створення у закладах освіти педагогічного спрямування відповідного «інформаційно-освітнього середовища»; $71,8 \%$ опитаних вважають, що мультимедійні засоби навчання допомагають краще зрозуміти і запам'ятати 
словесні ігри, які є обов'язковими при застосуванні педагогіки Ф. Фребеля на практиці. Опитування також засвідчило, що 26,96\% студентів надають перевагу онлайн-сервісу Prezi як альтернативному й ефективному засобу для створення електронних презентацій, що, на їх думку, сприяє кращому розумінню й реалізації в освітньому просторі педагогічної спадщини Ф. Фребеля.

У подальшому плануємо розширити дидактичні матеріали з використанням «Дарунків Ф. Фребеля» (дари № 2,3,4,5) у хмарному онлайн-сервісі Prezi для студентів педагогічних спеціальностей, значення i вагомість яких вкрай потрібні у майбутній професійній діяльності.

\section{СПИСОК ВИКОРИСТАНИХ ДЖЕРЕЛ}

Лебедева, М. и Шилова, О. (2004). Что такое ИКТ-компетентность студентов педагогического университета и как ее формировать? Информатика и образование, № 3, с. 95-100.

Анісімова, О. (2013). Методологічні основи педагогічної системи Ф. Фребеля. Педагогіка вищої та середньої школи : зб. наукових праць. Випуск 37. Кривий Ріг, с. 424-427.

Петухова, Л. (2011). Фрьобельпедагогіка - шлях до інтеграції освітніх систем України та Німеччини. Свропейські інтеграційні прочеси в Украйні: стан, проблеми та перспективи: зб. Всеукр. практ. конф. Херсон, с . 24-25.

Полєвікова, О. (2012). Ф. Фрьобель: обгрунтування необхідності суспільного дошкільного виховання. Інтеграція сучасних освітніх систем Свропи та світу в контексті впровадження педагогічних ідей Ф.Фрьобеля: зб. матеріалів міжн.наук.-прак. семінару. Херсон, с. 112-114.

Брушневська, I. (2017). Використання ідей Ф. Фребеля в корекційній роботі з дітьми дошкільного віку : моnografie Wydziału Pedagogiki i Psychologii WSEI Pedagogika Froebla wyzwaniem dla nauczycieli, szansą dla dzieci. Teoria i praktyka. Lublin, c. 97-107.

Стасюк, Д. (2019). Дарунки Ф. Фребеля як альтернативна логопедична технологія у подоланні мовленнєвих розладів у дітей дошкільного віку. Вектор пошуку у сучасному освітньому просторі: зб. Матер. VII Всеукраїнської наук.-практ. конф. Луцьк, с. 78-80

Фребель, Ф. (1974). Воспитание человека. История дошкольной и зарубежной педагогіки. Москва: Просвещение, 464 с.

Соменко, Д. (2015). Розвиток пізнавальної активності студентів педагогічних університетів у процесі навчання фізики з використанням інформаційно-комунікаційних технологій. Кандидат педагогічних наук. Кіровоград, 212 с.

Бондаренко, Т. (2018). Особливості використання програмного засобу Prezi у процесі розробки навчальних презентацій. Інформачійні технологї̈ $і$ засоби навчання. Том 63, №1. URL: https://www.researchgate.net/publication/331403123_OSOBLIVOSTI_VIKORISTANNA_PROGRA MNOGO_ZASOBU_PREZI_U_PROCESI_ROZROBKI_NAVCALNIH_PREZENTACIJ [Дата звернення 1 лютого 2020 року].

\section{REFERENCES}

Lebedeva, M. i Shylova, O. (2004). Chto takoe IKT-kompetentnost studentov pedagogicheskogo universiteta i kak ee formirovat? [What Is the ICT Competence in Students of Pedagogical University and How to Form It?]. Informatika i obrazovanie, No 3, s. 95-100. (in Russian)

Anisimova, O. (2013). Metodolohichni osnovy pedahohichnoi systemy F. Frebelia [Methodological Foundations of F. Frebel's pedagogical system]. Pedagogical Pedahohika vyshchoi ta serednoi shkoly: zb. naukovykh prats. Vypusk 37. Kryvyi Rih, s. 424-427. (in Ukrainian) 
Petukhova, L. (2011). Frobelpedahohika - shliakh do intehratsii osvitnikh system Ukrainy ta Nimechchyny [Frebel Pedagogy as a Way to Integrate the Educational Systems of Ukraine and Germany]. Yevropeiski intehratsiini protsesy v Ukraini: stan, problemy ta perspektyvy : zb. Vseukr. prakt. konf. Kherson, s. 24-25. (in Ukrainian)

Polievikova, O. (2012). F. Frobel: obgruntuvannia neobkhidnosti suspilnoho doshkilnoho vykhovannia [F. Frobel: Substantiation of the Need for Public Preschool Education]. Intehratsiia suchasnykh osvitnikh system Yevropy ta svitu $v$ konteksti vprovadzhennia pedahohichnykh idei F.Frobelia: zb. materialiv mizhn.nauk.-prak. seminaru. Kherson, s. 112-114. (in Ukrainian)

Brushnevska, I. (2017). Vykorystannia idei F. Frebelia v korektsiinii roboti z ditmy doshkilnoho viku [Using Frebel's Ideas in Correctional Work with Preschool Children] : monografie Wydziatu Pedagogiki i Psychologii WSEI Pedagogika Froebla - wyzwaniem dla nauczycieli, szansa dla dzieci. Teoria i praktyka. Lublin, s. 97-107. (in Ukrainian)

Stasiuk, D. (2019). Darunky F. Frebelia yak alternatyvna lohopedychna tekhnolohiia u podolanni movlennievykh rozladiv u ditei doshkilnoho viku [F. Frebel's Gifts as an Alternative Speech and Speech Therapy in Overcoming Speech Disorders in Preschool Children]. Vektor poshuku u suchasnomu osvitnomu prostori: zb. Mater. VII Vseukrainskoi nauk.-prakt. konf. Lutsk, ss. 78-80. (in Ukrainian)

Frebel, F. (1974). Vospitanie cheloveka. Istoryia doshkolnoi i Zarubezhnoi Pedagogiki [Upbringing a Person. The History of Preschool and Foreign Pedagogy]. Moskva: Prosveshchenye, 464 s. (in Russian)

Somenko, D. (2015). Rozvytok piznavalnoi aktyvnosti studentiv pedahohichnykh universytetiv $u$ protsesi navchannia fizyky z vykorystanniam informatsiino-komunikatsiinykh tekhnolohii [Development of Cognitive Activity of Students of Pedagogical Universities in the Process of Learning Physics Using Information and Communications Technology]. Candidat Pedahihichnykh nauk. Kirovohrad, 212 s. (in Ukrainian)

Bondarenko, T. (2018). Osoblyvosti vykorystannia prohramnoho zasobu Prezi u protsesi rozrobky navchalnykh prezentatsii [Features of Using Prezi Software in the Process of Developing Training Presentations]. Informatsiini tekhnolohii i zasoby navchannia, [online] Tom 63, №1. [on line] URL: https://www.researchgate.net/publication/331403123_OSOBLIVOSTI_VIKORISTANNA_PROGRA MNOGO_ZASOBU_PREZI_U_PROCESI_ROZROBKI_NAVCALNIH_PREZENTACIJ [Data zvernennia 1 liutoho 2020 roku]. (in Ukrainian)

\section{F. FROEBEL'S INNOVATIVE PEDAGOGY USING “PREZI" ONLINE SERVICE}

Nataliia Denysenko

Ph.D. in Pedagogy, Associate Professor at the Department of Human Health and Physical Rehabilitation, Academy of Recreational Technology and Law, Lutsk, Ukraine ORCID: 0000-0001-5730-0221 e-mail: Zaochnevid@gmail.com

Tetiana Bortniuk

Ph.D. in Economy, Lecture in Economics, Lutsk Pedagogical College, Lutsk, Ukraine ORCID: 0000-0001-9673-1366 


\author{
Nadiia Nait \\ Master in Philology, Postgraduate at Lesia Ukrainka \\ Eastern European National University, \\ Lecture of the Literary disciplines, \\ Lutsk Pedagogical College, \\ Lutsk, Ukraine \\ ORCID: 0000-0002-3520-1756 \\ e-mail:nadiaknight23@gmail.com
}

Daria Stasiuk

Preschool Education Specialist, Postgraduate at Lesia Ukrainka Eastern European National University, Lecture of pre-school teaching methods, Lutsk Pedagogical College, Lutsk, Ukraine ORCID: 0000-0002-4073-7483 e-mail: dasha-sinaya@ukr.net

\begin{abstract}
The article states that the use of informational technologies, multimedia tools and various online services greatly expand the possibilities of the educational process, provide new ways of presenting information, create the opportunity to test your own ideas and projects, promote better perception and absorption of knowledge, increase the interest in learning, training, motivation, and dynamic delivery of material. It is emphasized that software products with presentation nature have partly taken on the function of textbooks and manuals, which greatly simplify the process of training a new generation teachers in a pedagogical college. The results of the survey of students of pedagogical colleges on the issues of their readiness for implementation of F. Froebel's pedagogical heritage in the further professional activity were analyzed.

Students' opinion on the effectiveness of the use of Froebel's didactic material was studied. This material is aimed to develop the physical abilities of children, their ability to constructive activity, which has become particular important today because it is the basic quality of a person, his nucleus, the central characteristic of a creative personality. The mini-textbook "F. Frebel's Ideas in Action: Theory and Practice of the Present" presents recommendations for the use of author's vocabulary games, which were collected by teachers of Lutsk Pedagogical College/ They are given in Ukrainian and English. Emphasis is made on the importance of the cloud-based online service "Prezi" for the creation of educational material for mastering the methodology of using the game "Froebel's Gifts" in a work with children of preschool and primary school age. Practical recommendations for the application of ready-made presentations made in the cloud-based online service 'Prezi' are developed and their e-mail addresses are systematized. It is pointed that informational technologies will help in the future to create author's educational materials for improving the methodology of using Froebel's gifts in the educational environment (both in preschool education and in the conditions of the new Ukrainian school).

Keywords: F. Froebel's Gifts; multimedia; multimedia services; cloud service; online service; "Prezi"; vocabulary games; future specialists; modern children.
\end{abstract}

